\title{
The formation of the sol-gel nanostructures of road bitumen by selecting chemical group composition
}

\author{
Authors:

\section{Natalya G. Evdokimova,} \\ Doctor of Engineering, Associate Professor of Department «Chemical and Technological Processes», Ufa State Petroleum \\ Technical University Branch of the University in the City of Salavat, Salavat, Bashkortostan, Russian, ruskih1.r@yandex.ru;

\section{Nadezhda A. Egorova,} \\ Senior Lecturer of Department «Chemical and Technological Processes», Ufa State Petroleum Technical University, \\ Branch of the University in the City of Salavat, Salavat, Bashkortostan, Russian, kushner-nadia@mail.ru;

\section{Diana P. Sultanova,} \\ Undergraduate of Department «Chemical and Technological Processes», Ufa State Petroleum Technical University, \\ Branch of the University in the City of Salavat, Salavat, Bashkortostan, Russian, d.ishkina@mail.ru;

\section{Elvira M. Kunakkulova,} \\ Undergraduate of Department «Chemical and Technological Processes», Ufa State Petroleum Technical University, \\ Branch of the University in the City of Salavat, Salavat, Bashkortostan, Russian, btp1421elvira@gmail.com;

\section{Natalia G. Serezhkina,} \\ Senior Lecturer of Department «General Scientific Disciplines», Ufa State Petroleum Technical University, \\ Branch of the University in the City of Salavat, Salavat, Bashkortostan, Russian, sng-tasha@yandex.ru
}

\footnotetext{
Abstract: The studies of paving bitumen chemical composition and physicochemical properties produced by compounding deeply oxidized bitumen, tar and vacuum gas-oil of different hydrocarbon composition are carried out.

The bitumen is marked to have the optimal complex of properties if the best chemical group composition of three main elements bitumen binding agents - oils, resins and asphaltenes - is formed. That provides the best structure of bitumen oildisperse system.

The object of the research is the selection of compounded paving bitumen chemical group composition that provides the formation of bitumen nanodisperse system as «sol-gel» which quality metrics match the requirements of the new State Standard 33133-2014 «Petroleum paving viscous bitumen».

The analysis of the research results makes it possible to determine the optimal chemical group composition of compounded bitumen that meets standard requirements by physicochemical properties. It has been determined that the higher the bitumen dispersion is, the more plastic properties it has. In addition, the bitumen ability to thermal-oxidative processes of deterioration decreases. The value range of bitumen dispersion and the most optimal values of asphaltenes ratio to the amount of oils and resins for bitumen grade BND 100/130 and for bitumen grade BND 70/100 were found. This amount of oils and resins for referred bitumen grades provide production of nanostructured bitumen as «sol-gel».

It is shown that when processing tar of different chemical composition the optimal chemical group composition of finished product can be formed by compounding. That rises probability that the end product will fit to the new State Standard 33133-2014. The represented results of the research can be used in fabrication as the modern laboratories of the oil-refining enterprises can determine quite efficiently the chemical composition of oil products used in compounding processes in bitumen binding agents production.
}

Keywords: bitumen, tar, nanodispersed systems, oils, resins, asphaltenes, chemical group composition, compounding, physicochemical properties.

For citation: Evdokimova N.G., Egorova N.A., Sultanova D.P., Kunakkulova E.M., Serezhkina N.G. The formation of the sol-gel nanostructures of road bitumen by selecting chemical group composition. Nanotehnologii $v$ stroitel'stve $=$ Nanotechnologies in Construction. 2019, Vol. 11, no. 5, pp. 512-525. DOI: 10.15828/2075-8545-2019-11-5-512-525. 
$<$ rel="license" href="http://creativecommons.org/licenses/by/4.0/" ><img alt="Creative Commons License" style="border-width:0" src="https://i.creativecommons. org/l/by/4.0/88x31.png" / $></ \mathrm{a}><$ br / $><$ span xmlns:dct="http://purl.org/dc/terms/" href="http://purl.org/dc/dcmitype/Text" property="dct:title" rel="dct:type" $>$ The formation of the sol-gel nanostructures of road bitumen by selecting chemical group composition</span $>$ by $<$ a xmlns:cc="http://creativecommons.org/ ns\#" href="Nanotehnologii v stroitel'stve = Nanotechnologies in Construction. 2019, Vol. 11, no. 5, pp. 512-525. DOI: 10.15828/2075-8545-2019-11-5-512-525" property="cc:attributionName" rel="cc:attributionURL" $>$ Evdokimova N.G., Egorova N.A., Sultanova D.P., Kunakkulova E.M., Serezhkina N.G. $</ a>$ is licensed under a $<$ a rel="license" href="http://creativecommons.org/licenses/by/4.0/" >Creative Commons Attribution 4.0 International License $</ a>$. $<$ br $/>$ Based on a work at $<$ a xmlns:dct="http://purl.org/dc/terms/" href="http://nanobuild.ru/en_EN/nanobuild-5-2019/" rel="dct:source" $>$ http://nanobuild.ru/en_EN/nanobuild-5-2019/</a $>$. <br />Permissions beyond the scope of this license may be available at <a xmlns:cc="http://creativecommons.org/ns\#" href="ruskih1.r@yandex.ru" rel="cc:morePermissio ns">ruskih1.r@yandex.ru</a $>$.

The paper has been received by editors: 22.08.2019.

The paper has been received by editors after peer-review: 04.09.2019.

The paper has been accepted for publication: 10.09.2019.

\section{Формирование золь-гелевой наноструктуры дорожных битумов методом подбора группового химического состава}

\section{Авторы:}

Евдокимова Наталья Георгиевна,

д-р. техн. наук, проф. каф. «Химико-технологические процессы», ФГБОУ ВО «Уфимский государственный нефтяной технический университет», филиал УГНТУ в г. Салавате, Салават, Башкортостан, Россия, ruskih1.r@yandex.ru;

\section{Егорова Надежда Александровна,}

ст. преподаватель каф. «Химико-технологические процессы» филиала ФГБОУ ВО «Уфимский государственный нефтяной технический университет» в г. Салават, Салават, Башкортостан, Россия, kushner-nadia@mail.ru;

\section{Султанова Диана Петровна,}

магистрант каф. «Химико-технологические процессы» филиала ФГБОУ ВО «Уфимский государственный нефтяной технический университет» в г. Салават, Салават, Башкортостан, Россия, d.ishkina@mail.ru;

\section{Кунаккулова Эльвира Маратовна,}

магистрант каф. «Химико-технологические процессы» филиала ФГБОУ ВО «Уфимский государственный нефтяной технический университет» в г. Салават, Салават, Башкортостан, Россия, btp1421elvira@gmail.com;

\section{Сережкина Наталья Геннадьевна,}

ст. преподаватель каф. «Общенаучные дисциплины» филиала ФГБОУ ВО «Уфимский государственный нефтяной технический университет» в г. Салават, Салават, Башкортостан, Россия, sng-tasha@yandex.ru

Резюме: В работе проведены исследования по изучению химического состава и физико-химических свойств дорожных битумов, полученных методом компаундирования глубокоокисленных битумов, гудронов и вакуумного газойля различного углеводородного состава. Отмечено, что битумы будут обладать оптимальным комплексом свойств, когда сформирован наилучший групповой химический состав трех основных элементов битумных вяжущих: масел, смол и асфальтенов, который в свою очередь формирует наилучшую структуру нефтяной дисперсной системы битума. Целью исследований стал подбор группового химического состава компаундированных дорожных битумов, который обеспечит образование нанодисперсной структуры битума типа «золь-гель», показатели качества которого будут соответствовать требованиям нового стандарта ГОСТ 33133-2014 «Битумы нефтяные дорожные вязкие».

Анализ результатов исследований позволил установить оптимальный групповой химический состав компаундированных битумов, соответствующих по физико-химическим свойствам требованиям стандарта. Установлено, что чем выше дисперсность битума, тем более пластичными свойствами он обладает, кроме того снижается способность битума к термоокислительным процессам старения. Найден диапазон значений дисперсности битума и наиболее оптимальные значения отношения асфальтенов к сумме масел и смол для битума марки БНД 100/130 и битума марки БНД 70/100, которые обеспечат получение наноструктурированного битума типа «золь-гель». 
Показано, что при переработке гудронов различного химического состава в битумном производстве методом компаундирования можно сформировать оптимальный групповой химический состав готовой продукции и с большей долей вероятности получить продукцию, соответствующую новому стандарту ГОСТ 33133-2014. Представленные в работе результаты могут быть квалифицированно использованы в производстве, т.к. современная лабораторная база нефтеперерабатывающих предприятий позволяет достаточно оперативно определять химический состав нефтепродуктов, используемых в процессах компаундирования при производстве битумных вяжущих.

Ключевые слова: битум, гудрон, нанодисперсные системы, масла, смолы, асфальтены, групповой химический состав, компаундирование, физико-химические свойства.

Для цитирования: Евдокимова Н.Г., Егорова Н.А., Султанова Д.П., Куннакулова Э.М., Сережкина Н.Г. Формирование золь-гелевой наноструктуры дорожных битумов методом подбора группового химического состава // Нанотехнологии в строительстве. - 2019. - Том 11, № 5. - С. 512-525. - DOI: 10.15828/2075-8545-2019-11-5-512-525.

Машиночитаемая информация о CС-лицензиях (HTML-код) в метаданных статьи

$<$ a rel="license" href="http://creativecommons.org/licenses/by/4.0/"><img alt="Creative Commons License" style="border-width:0" src="https://i.creativecommons. org/l/by/4.0/88x31.png" / ></a $><$ br / $><$ span xmlns:dct="http://purl.org/dc/terms/" href="http://purl.org/dc/dcmitype/Text" property="dct:title" rel="dct:type" $>$ The formation of the sol-gel nanostructures of road bitumen by selecting chemical group composition</span $>$ by $<$ a xmlns:cc="http://creativecommons.org/ ns\#" href="Nanotehnologii v stroitel'stve = Nanotechnologies in Construction. 2019, Vol. 11, no. 5, pp. 512-525. DOI: 10.15828/2075-8545-2019-11-5-512-525" property="cc:attributionName" rel="cc:attributionURL" $>$ Evdokimova N.G., Egorova N.A., Sultanova D.P., Kunakkulova E.M., Serezhkina N.G. $</$ a $>$ is licensed under a $<$ a rel="license" href="http://creativecommons.org/licenses/by/4.0/" $>$ Creative Commons Attribution 4.0 International License $</ a>.<b r />$ Based on a work at $<$ a xmlns:dct="http://purl.org/dc/terms/" href="http://nanobuild.ru/en_EN/nanobuild-5-2019/" rel="dct:source" >http://nanobuild.ru/en_EN/nanobuild-5-2019/</a $>$.<br />Permissions beyond the scope of this license may be available at <a xmlns:cc="http://creativecommons.org/ns\#" href="ruskih1.r@yandex.ru" rel="cc:morePermissio ns">ruskih1.r@yandex.ru</a $>$.

Статья поступила в редакцию: 22.08.2019.

Статья поступила в редакцию после рецензирования: 04.09.2019.

Статья принята к публикации: 10.09.2019.

\section{INTRODUCTION}

$\mathrm{T}$ he use of the high-quality petroleum bitumen provides durability of asphalt coverings under heavy traffic conditions. The quality of bitumen as that of the petroleum disperse systems is directly connected with their structures and properties that are defined by the proportion of oils, resins and asphaltenes [1-9]. These three main structural elements of bitumen binding agents interact and form the variety of microheterogeneous nanodisperse structure [10-13].

One of the available and effective methods of petroleum bitumen production is the processing based on mixing deeply oxidized bitumen with heavy still bottoms (tar) - «compounding» [14-17]. This technology is introduced in some Russian enterprises. It permits to enlarge the production stock and to improve the petroleum bitumen properties. The best chemical group composition of bitumen and its dispersion [18-21] can be got by selecting the optimal ratio of compounds and the finished product will match the State Standard 33133-2014.

The bitumen will have the optimal complex of properties only if it has the best chemical group composition from oils, resins and asphaltenes and the definite structure of petroleum disperse systems is formed. The studies of bitumen cross-linking processes permit to bring out the possible disperse structures forming in bitumen against the quantity and nature of asphaltenes, the kind of hydrocarbons and the quantity of resins in disperse environment.

The results represented in the research [22] show the dependence of bitumen running abilities from their chemical composition that is characterized by the scales of asphaltenes content ratio to resins content $(\mathrm{A} / \mathrm{R})$ and ratio of asphaltenes and resins amount to resins content $(\mathrm{A}+\mathrm{R}) / \mathrm{O}$. It is set up that the heat -and cold-resistant bitumen with high strength must have $23 \%$ mass. of resins, $15-18 \%$ mass. of asphaltenes, $52-54 \%$ mass. of oils and ratio must be $\mathrm{A} / \mathrm{R}=0,5-0,6$ and $(\mathrm{A}+\mathrm{R}) / \mathrm{O}=0,8-0,9$.

A.S. Kolbanovskaya [19, 23, 24] suggested her own bitumen classification having associated the nature of space supramolecular structure of bitumen with the content of main components in them and interaction degree between the particles of bitumen disperse stage. She defined three types of bitumen structure: «gel», «sol» and «solgel». The «sol-gel» structure is the optimal structure for bitumen. The usage of optimal structural sol-gel bitumen increases the durability of asphalt coverings for 1 , 
5-3 times in comparison with the coverings based on the bitumen of another structure [1]. According to her mind the bitumen must have the content of asphaltenes in the range $21-23 \%$, resins $-29-34 \%$, oils $-46-50 \%$. The ratio of asphaltenes to the total amount of asphalt resinous substances $(\mathrm{A} /(\mathrm{S}+\mathrm{A}))$ must be $0,39-0,44$ and the ratio of asphaltenes to the amount of oils and resins $(\mathrm{A} /(\mathrm{M}+\mathrm{S}))-0,25-0,30$.

Oil of new fields or its mixture is involved in the process of refining. The asphaltenes and resins nature and structure, hydrocarbons of this oil are different from that used before. Everything will influence the properties of raw materials for bitumen production and bitumen itself. That is why the investigations, directed to studying and definition of modern bitumen chemical composition, are necessary because these results permit to form qualitative nanostructured bitumen binding agent of optimal structure for durable asphalt coverings.

The object of the research is the selection of the best group hydrocarbon composition of compounded paving bitumen that provides the formation of bitumen nanodisperse system as «sol-gel» which quality metrics match

\section{Table 1}

Quality indicators of tar and deeply oxidized bitumen

\begin{tabular}{|l|c|c|c|c|}
\hline \multirow{2}{*}{ Factors } & \multicolumn{4}{c|}{ Raw material } \\
\cline { 2 - 5 } & Tar I & Bitumen I & Tar II & Bitumen II \\
\hline Conditional viscosity at $80^{\circ} \mathrm{C}$, sec. & 96 & - & 87 & - \\
\hline Change of softening temperature after deterioration, ${ }^{\circ} \mathrm{C}$ & 4 & 8 & 4 & 8 \\
\hline Density at $15^{\circ} \mathrm{C}, \mathrm{kg} / \mathrm{m}^{3}$ & 1001 & - & 1007 & - \\
\hline Temperature of flash in the open bowl, ${ }^{\circ} \mathrm{C}$ & 341 & - & 332 & - \\
\hline Temperature of softening over ring and ball, ${ }^{\circ} \mathrm{C}$ & 34 & 81 & 32 & 64 \\
\hline Depth of needle penetration at $25^{\circ} \mathrm{C}, 0,1 \mathrm{~mm}$ & - & 42 & - & 38 \\
\hline
\end{tabular}

\section{Table 2}

Physicochemical properties of vacuum gas-oil fraction

\begin{tabular}{|l|c|}
\hline \multicolumn{1}{|c|}{ Factor nomination } & Values \\
\hline Density at $20^{\circ} \mathrm{C}, \mathrm{kg} / \mathrm{m}^{3}$ & 900 \\
\hline Temperature of distillation starting, ${ }^{\circ} \mathrm{C}$ & 180 \\
\hline Oil products volume boils-off to $350^{\circ} \mathrm{C}, \%$ & 35 \\
\hline Temperature of distillation termination, ${ }^{\circ} \mathrm{C}$ & 500 \\
\hline Volume fraction of excise tar, $\%$ & 15 \\
\hline Flash temperature, ${ }^{\circ} \mathrm{C}$ & 220 \\
\hline
\end{tabular}

Table 3

Group hydrocarbon composition of research subjects the requirements of the new State Standard 33133-2014 «Petroleum paving viscous bitumen».

The subject of the research: Tar (tar I, tar II), deeply oxidized bitumen (bitumen I, bitumen II) produced from this tar and vacuum gas-oil (VG) of primary oil refining installation were used as the subjects of research. The main factor of substances quality used here are shown in tables $(1,2)$.

The group hydrocarbon composition was determined at the laboratory installation «Gradient-M» with the thermal conduction sensor by the fluid absorbtion chromatography method with gradient driving. This

\begin{tabular}{|l|c|c|c|c|c|}
\hline \multirow{2}{*}{\multicolumn{1}{c|}{ Group combination nomination }} & \multicolumn{5}{c|}{ Content, \% mass. } \\
\cline { 2 - 6 } & Tar I & Tar II & Bitumen I & Bitumen II & Vacuum gas-oil \\
\hline Paraffin naphthene hydrocarbons & 26,8 & 24,8 & 29,8 & 23,8 & 73,6 \\
\hline Light aromatic hydrocarbons & 13,7 & 15,6 & 9,0 & 10,1 & 8,6 \\
\hline Medium aromatic hydrocarbons & 1,0 & 1,8 & 1,7 & 2,4 & 1,7 \\
\hline Heavy aromatic hydrocarbons & 36,2 & 33,3 & 21,0 & 21,4 & 12,0 \\
\hline Amount of oils & 77,7 & 75,5 & 61,5 & 57,7 & 95,9 \\
\hline Resins & 19,9 & 20,3 & 20,0 & 24,0 & 2,6 \\
\hline Asphaltenes & 2,4 & 4,2 & 18,5 & 18,3 & 1,5 \\
\hline
\end{tabular}


technique permits to define the group composition of heavy-oil products with the least error. The heavyoil products are divided into seven groups: paraffin naphthene hydrocarbons, light aromatic hydrocarbons, medium aromatic hydrocarbons, heavy aromatic hydrocarbons, resins and asphaltenes. Group hydrocarbon composition of components used in the research is represented in the table 3 .

The results of research: The bitumen samples with softening temperatures of $45^{\circ} \mathrm{C}$ and $47^{\circ} \mathrm{C}$ were prepared by the method of compounding. The composition and chemical group composition of compounded bitumen got on base of raw material I, II and vacuum gas-oil are represented in tables $(4,5)$ and their physicochemical properties are in the tables $(6,7)$.

The physicochemical properties of obtained bitumen samples on base of raw material I and II are represented in tables $(6,7)$.
The analysis of the research results made it possible to set the optimal chemical group composition of compounded bitumen represented on the pictures 1 and 2 .

One of the most important piculiarities of nanostructured bitumen system is dispersion that describes not only particles size of disperse phase in disperse system, shows the number of particles that can be put closely in one cubic meter, but also dispersion influences the physicochemical properties of bitumen binding agent. The more is the size of bitumen disperse phase, formed by asphaltenes generaly, the more is its dispersion. The dispersion of the examined bitumen was defined according to [1]. The picture 3 shows dependences of asphaltenes ratio to the mount of oils and resins $(\mathrm{A} /(\mathrm{O}+\mathrm{R})$ from dispersion of compounded bitumen.

It has been determined that the higher the bitumen dispersion is, the more plastic properties it has. In addition, the bitumen ability to thermal-oxidative processes

\section{Table 4}

Composition and chemical group composition of compounded bitumen produced on the basis of raw material I, II and vacuum gas-oil

\begin{tabular}{|c|c|c|c|c|c|c|}
\hline \multirow{2}{*}{$\begin{array}{l}\text { Sample } \\
\text { number }\end{array}$} & \multicolumn{3}{|c|}{ Components content, $\%$} & \multicolumn{3}{|c|}{ Content, \% } \\
\hline & Bitumen & Tar & VG & Oils & Resins & Asphaltenes \\
\hline 1 & 49 & 46 & 5 & 71 & 19 & 10 \\
\hline 2 & 66 & 24 & 10 & 69 & 18 & 13 \\
\hline 3 & 60 & 25 & 15 & 71 & 17 & 12 \\
\hline 4 & 60 & 20 & 20 & 72 & 17 & 12 \\
\hline 5 & 60 & 35 & 5 & 69 & 19 & 12 \\
\hline 6 & 73 & 17 & 10 & 68 & 18 & 14 \\
\hline 7 & 70 & 15 & 15 & 69 & 17 & 14 \\
\hline 8 & 75 & 5 & 20 & 69 & 17 & 14 \\
\hline
\end{tabular}

Table 5

Composition and chemical group composition of compounded bitumen produced on the basis of raw material I, II and vacuum gas-oil

\begin{tabular}{|c|c|c|c|c|c|c|}
\hline \multirow{2}{*}{$\begin{array}{c}\text { Sample } \\
\text { number }\end{array}$} & \multicolumn{3}{|c|}{ Components content, $\%$} & \multicolumn{3}{c|}{ Content, $\%$} \\
\cline { 2 - 7 } & Bitumen & Tar & VG & Oils & Resins & Asphaltenes \\
\hline 1 & 60 & 35 & 5 & 66 & 22 & 13 \\
\hline 2 & 68 & 22 & 10 & 65 & 21 & 14 \\
\hline 3 & 85 & 0 & 15 & 63 & 21 & 16 \\
\hline 4 & 65 & 30 & 5 & 65 & 22 & 13 \\
\hline 5 & 75 & 15 & 10 & 64 & 21 & 15 \\
\hline 6 & 82 & 3 & 15 & 64 & 21 & 15 \\
\hline
\end{tabular}


Table 6

Physicochemical properties of bitumen produced on the basis of raw material I and vacuum gas-oil

\begin{tabular}{|c|c|c|c|c|c|c|c|c|c|c|}
\hline \multirow{2}{*}{ Factor } & \multicolumn{8}{|c|}{ Number of bitumen sample } & \multicolumn{2}{|c|}{$\begin{array}{c}\text { State Standard } \\
33133-2014\end{array}$} \\
\hline & 1 & 2 & 3 & 4 & 5 & 6 & 7 & 8 & $\begin{array}{c}\text { BND } \\
100 / 130\end{array}$ & $\begin{array}{c}\text { BND } \\
70 / 100\end{array}$ \\
\hline $\begin{array}{l}\text { Softening } \\
\text { temperature, }{ }^{\circ} \mathrm{C}\end{array}$ & 46 & 45 & 45 & 45 & 47 & 47 & 47 & 47 & \begin{tabular}{|l} 
not lower \\
than 45
\end{tabular} & $\begin{array}{l}\text { not lower } \\
\text { than } 47\end{array}$ \\
\hline $\begin{array}{l}\text { Change of softening tem- } \\
\text { perature after deteriora- } \\
\text { tion, }{ }^{\circ} \mathrm{C}\end{array}$ & 4 & 4 & 7 & 11 & 7 & 11 & 10 & 7 & $\begin{array}{l}\text { not more } \\
\text { than } 7\end{array}$ & $\begin{array}{c}\text { not more } \\
\text { than } 7\end{array}$ \\
\hline $\begin{array}{l}\text { Change sample mass af- } \\
\text { ter deterioration, } \% \text { mass. }\end{array}$ & 0 & 0 & 0 & 0 & 0,51 & 0 & 0 & 0 & \begin{tabular}{|l|} 
not more \\
than 0,7
\end{tabular} & $\begin{array}{l}\text { not more } \\
\text { than } 0,6\end{array}$ \\
\hline $\begin{array}{l}\text { Depth of needle penetra- } \\
\text { tion at } 0^{\circ} \mathrm{C} \cdot 0,1 \mathrm{~mm}\end{array}$ & 51 & 54 & 56 & 49 & 42 & 49 & 47 & 42 & 30 & 21 \\
\hline $\begin{array}{l}\text { Depth of needle penetra- } \\
\text { tion at } 25^{\circ} \mathrm{C} \cdot 0,1 \mathrm{~mm}\end{array}$ & 130 & 139 & 140 & 142 & 102 & 93 & 97 & 100 & $101-130$ & $71-100$ \\
\hline Stretchability at $25^{\circ} \mathrm{C}, \mathrm{cm}$ & 77 & 48 & 73 & 65 & 45 & 37 & 18 & 62 & $\begin{array}{l}\text { not less } \\
\text { than } 70\end{array}$ & $\begin{array}{l}\text { not less } \\
\text { than } 62\end{array}$ \\
\hline $\begin{array}{l}\text { Brittleness } \\
\text { temperature, }{ }^{\circ} \mathrm{C}\end{array}$ & -25 & -29 & -27 & -28 & -26 & -34 & -30 & -26 & $\begin{array}{c}\text { not } \\
\text { higher } \\
\text { than }-20\end{array}$ & $\begin{array}{c}\text { not } \\
\text { higher } \\
\text { than }-18\end{array}$ \\
\hline
\end{tabular}

\section{Table 7}

Physicochemical properties of bitumen produced on the basis of raw material II and vacuum gas-oil

\begin{tabular}{|c|c|c|c|c|c|c|c|c|}
\hline \multirow{2}{*}{ Factor } & \multicolumn{6}{|c|}{ Number of bitumen sample } & \multicolumn{2}{|c|}{ State Standard 33133-2014 } \\
\hline & 1 & 2 & 3 & 4 & 5 & 6 & BND 100/130 & BND 70/100 \\
\hline Softening temperature, ${ }^{\circ} \mathrm{C}$ & 46 & 46 & 45 & 47 & 48 & 47 & $\begin{array}{c}\text { not lower than } \\
45\end{array}$ & $\begin{array}{c}\text { not lower than } \\
47\end{array}$ \\
\hline $\begin{array}{l}\text { Change of softening tempera- } \\
\text { ture after deterioration, }{ }^{\circ} \mathrm{C}\end{array}$ & 6 & 6 & 6 & 5 & 8 & 4 & $\begin{array}{c}\text { not more than } \\
7\end{array}$ & $\begin{array}{c}\text { not more than } \\
7\end{array}$ \\
\hline $\begin{array}{l}\text { Change sample mass after } \\
\text { deterioration, } \% \text { mass. }\end{array}$ & 0 & 0 & 0,43 & 0 & 0,43 & 0 & $\begin{array}{c}\text { not more than } \\
0,7\end{array}$ & $\begin{array}{c}\text { not more than } \\
0,6\end{array}$ \\
\hline $\begin{array}{l}\text { Depth of needle penetration } \\
\text { at } 0^{\circ} \mathrm{C} \cdot 0,1 \mathrm{~mm}\end{array}$ & 41 & 37 & 54 & 36 & 43 & 44 & 30 & 21 \\
\hline $\begin{array}{l}\text { Depth of needle penetration } \\
\text { at } 25^{\circ} \mathrm{C} \cdot 0,1 \mathrm{~mm}\end{array}$ & 104 & 110 & 118 & 80 & 82 & 83 & $101-130$ & $71-100$ \\
\hline Stretchability at $25^{\circ} \mathrm{C}, \mathrm{cm}$ & 74 & 69 & 58 & 41 & 51 & 76 & $\begin{array}{l}\text { not less than } \\
70\end{array}$ & $\begin{array}{l}\text { not less than } \\
62\end{array}$ \\
\hline Brittleness temperature, ${ }^{\circ} \mathrm{C}$ & -27 & -25 & -32 & -28 & -32 & -32 & $\begin{array}{l}\text { not higher } \\
\text { than }-20\end{array}$ & $\begin{array}{l}\text { not higher } \\
\text { than }-18\end{array}$ \\
\hline
\end{tabular}

of deterioration decreases. The value range of bitumen dispersion $(2,7-3,5)$ and the most optimal ratio (A/

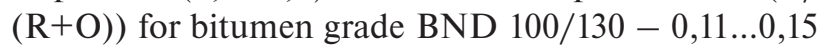

and for bitumen grade BND 70/130 - 0,16 ..0,18 that provide production of nanostructured bitumen as «solgel» were found. 


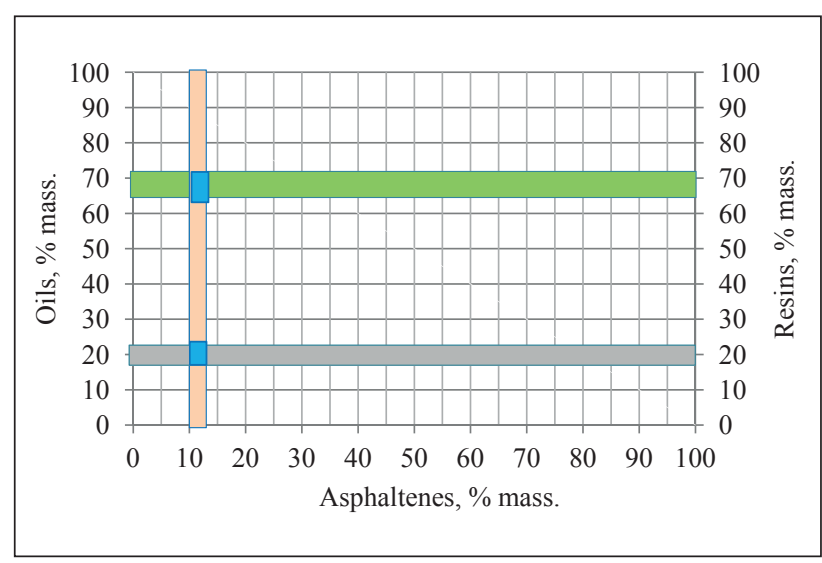

Fig. 1. Optimal chemical group composition of compounded bitumen for the grade BND 100/130

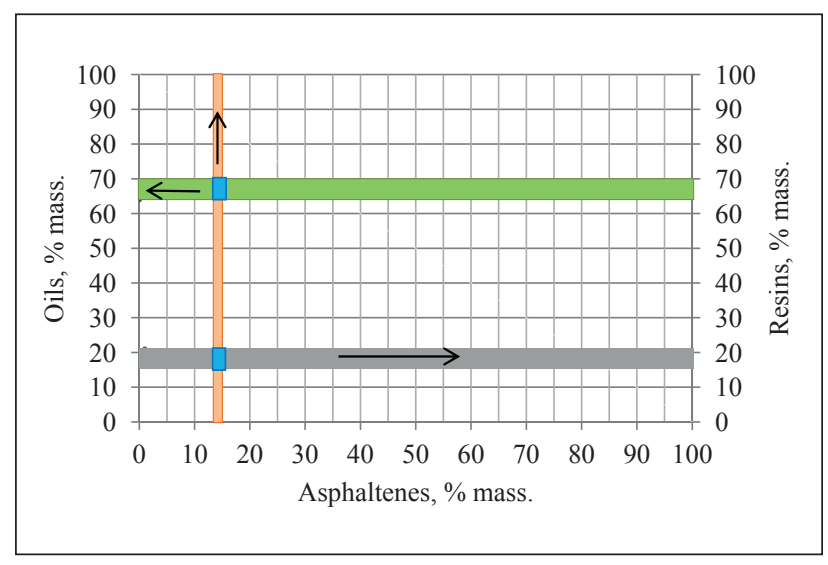

Fig. 2. Optimal chemical group composition of compounded bitumen for the grade BND 70/100

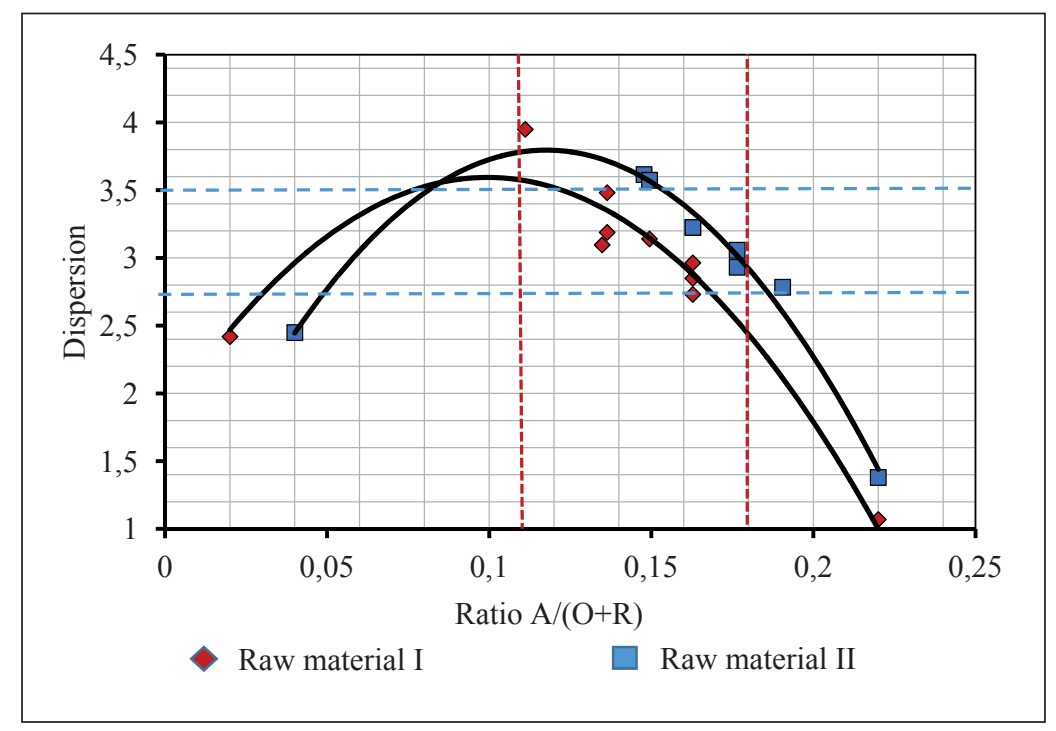

Fig. 3. Dependences of asphaltenes ratio to the mount of oils and resins $(\mathrm{A} /(\mathrm{O}+\mathrm{R})$ on dispersion of compounded bitumen produced on the basis of raw material I and II and vacuum gas-oil

\section{CONCLUSION}

Thus, when processing tar of different chemical composition the optimal chemical group composition of finished product can be formed by compounding. That rises probability that the end product will fit to the new State Standard 33133-2014.
The modern laboratories of the oil-refining enterprises can determine quite efficiently the chemical composition of oil products. Therefore the results represented here can be applied in production efficiently. 


\section{ВВЕДЕНИЕ}

$\Pi$ рименение высококачественных нефтяных битумов обеспечивает долговечность асфальтобетонных покрытий в условиях интенсивного движения автотранспорта. Качество битумов как нефтяных дисперсных систем непосредственно связано с их структурой и свойствами, которые определяются количественным соотношением масел, смол и асфальтенов [1-9]. Эти три основных структурных элемента битумных вяжущих взаимодействуют между собой и образуют ту или иную разновидность микрогетерогенной нанодисперсной структуры [10-13].

Одним из перспективных и эффективных методов получения нефтяных битумов является технология, основанная на смешении глубокоокисленного битума с тяжелыми нефтяными остатками (гудронами) «окисление-компаундирование» [14-17]. Данная технология внедрена на некоторых российских предприятиях. Она позволяет расширить ассортимент выпускаемой продукции и улучшить свойства нефтяных битумов. В результате подбора оптимального соотношения компаундов можно достичь наилучшего группового химического состава битума и его дисперсности [18-21] и получить готовую битумную продукцию, соответствующую ГОСТ 33133-2014.

Битумы будут обладать оптимальным комплексом свойств только в том случае, когда они имеют наилучший групповой химический состав из масел, смол и асфальтенов и сформирована определенная структура нефтяной дисперсной системы. Исследования процессов структурообразования битумов позволяют выявить возможные дисперсные структуры, образующиеся в битуме в зависимости от количества и природы асфальтенов, вида углеводородов и количества смол в дисперсионной среде.

Результаты, представленные в работе [22], свидетельствуют о зависимости эксплуатационных свойств битумов от их химического состава, который характеризуется величинами отношения содержания асфальтенов к содержанию смол (А/C) и суммой асфальтенов и смол к содержанию масел $(\mathrm{A}+\mathrm{C}) / \mathrm{M}$. Установлено, что битумы тепло- и морозостойкие с высокой прочностью должны содержать $23 \%$ масс. смол, 15-18\% масс. асфальтенов, 52-54\% масс. масел и иметь соотношения А/C $=0,5-0,6$ и $(\mathrm{A}+\mathrm{C}) / \mathrm{M}=0,8-0,9$.

Колбановская А.С. [19, 23, 24] предложила свою систему классификации битумов, связав характер

\section{Таблииа 1}

Показатели качества гудронов и глубокоокисленных битумов

\begin{tabular}{|l|c|c|c|c|}
\hline \multicolumn{1}{|c|}{ Наименование показателей } & \multicolumn{3}{|c|}{ Наименование сырья } \\
\cline { 2 - 5 } & Гудрон I & Битум I & Гудрон II & Битум II \\
\hline Условная вязкость при $80^{\circ} \mathrm{C}$, сек. & 96 & - & 87 & - \\
\hline $\begin{array}{l}\text { Изменение температуры размягчения } \\
\text { после старения, }{ }^{\circ} \mathrm{C}\end{array}$ & 4 & 8 & 4 & 8 \\
\hline Плотность при $15^{\circ} \mathrm{C}, \mathrm{Kг} / \mathrm{M}^{3}$ & 1001 & - & 1007 & - \\
\hline Температуры вспышки в открытом тигле, ${ }^{\circ} \mathrm{C}$ & 341 & - & 332 & - \\
\hline Температура размягчения по КиШ, ${ }^{\circ} \mathrm{C}$ & 34 & 81 & 32 & 64 \\
\hline Глубина проникания иглы при $25^{\circ} \mathrm{C}, 0,1 \mathrm{Mм}$ & - & 42 & - & 38 \\
\hline
\end{tabular}

\section{Таблииа 2}

Физико-химические свойства фракции вакуумного газойля

\begin{tabular}{|l|c|}
\hline \multicolumn{1}{|c|}{ Наименование показателей } & Значения \\
\hline Плотность при $20^{\circ} \mathrm{C}, \mathrm{\kappa г} / \mathrm{M}^{3}$ & 900 \\
\hline Температура начала перегонки, ${ }^{\circ} \mathrm{C}$ & 180 \\
\hline До $350^{\circ} \mathrm{C}$ выкипает, $\%$ об & 35 \\
\hline Температура конца перегонки, ${ }^{\circ} \mathrm{C}$ & 500 \\
\hline Объемная доля акцизных смол, $\%$ & 15 \\
\hline Температура вспышки, ${ }^{\circ} \mathrm{C}$ & 220 \\
\hline
\end{tabular}

пространственной надмолекулярной структуры битумов с содержанием в них основных компонентов и степень взаимодействия между частицами дисперсной фазы битума. Она выделила три типа структур битума: «гель», «золь» и «золь-гель». Структура «зольгель» является оптимальной структурой для битумов. Применение битумов оптимального структурного золь-гелевого типа обеспечивает увеличение срока службы дорожных покрытий в 1,5-3 раза по сравнению с покрытиями на основе битумов другой структуры [1]. По ее мнению, в битумах должно быть содержание асфальтенов в пределах 21-23\% масс., смол - 29-34\% масс. и масел - 46-50\% масс. При 
Таблица 3

Групповой углеводородный состав объектов исследования

\begin{tabular}{|l|c|c|c|c|c|}
\hline \multirow{2}{*}{ Наименование групповых соединений } & \multicolumn{5}{|c|}{ Содержание, \% масс. } \\
\cline { 2 - 6 } & Гудрон I & Гудрон II & Битум I & Битум II & $\begin{array}{c}\text { Вакуумный } \\
\text { газойль }\end{array}$ \\
\hline Парафино-нафтеновые углеводороды & 26,8 & 24,8 & 29,8 & 23,8 & 73,6 \\
\hline Легкие ароматические углеводороды & 13,7 & 15,6 & 9,0 & 10,1 & 8,6 \\
\hline Средние ароматические углеводороды & 1,0 & 1,8 & 1,7 & 2,4 & 1,7 \\
\hline Тяжелые ароматические углеводороды & 36,2 & 33,3 & 21,0 & 21,4 & 12,0 \\
\hline Сумма масел & 77,7 & 75,5 & 61,5 & 57,7 & 95,9 \\
\hline Смолы & 19,9 & 20,3 & 20,0 & 24,0 & 2,6 \\
\hline Asphaltenes & 2,4 & 4,2 & 18,5 & 18,3 & 1,5 \\
\hline
\end{tabular}

этом отношение асфальтенов к общей сумме асфальто-смолистых веществ (A/ $(\mathrm{C}+\mathrm{A}))$ должно быть 0,39-0,44, а отношение асфальтенов к сумме масел и смол $(\mathrm{A} /(\mathrm{M}+\mathrm{C}))-0,25-0,30$.

Однако в процессы переработки вовлекается нефть новых месторождений или ее смеси. Природа и структура асфальтенов, смол и виды углеводородов этой нефти отличны от тех, которая перерабатывалась ранее, и будут оказывать существенное влияние на свойства как сырья битумного производства, так и самих битумов. Поэтому исследования, направленные на изучение и определение химического состава современных битумов, являются необходимыми, т.к. полученные результаты позволят сформировать качественное наноструктурированное битумное вяжущее оптимальной структуры для долговечных асфальтобетонных дорожных покрытий.

Целью исследований стал подбор наилучшего группового углеводородного состава компаундированных дорожных битумов, который обеспечит образование нанодисперсной структуры битума типа «золь-гель», показатели качества которого обеспечат требования нового стандарта ГОСТ 33133-2014 «Битумы нефтяные дорожные вязкие».

Объекты исследований. В качестве объектов исследований были использованы гудроны (гудрон I, гудрон II), глубокоокисленные битумы (битум I, битум II), полученные их этих гудронов, и вакуумный газойль (ВГ) установки первичной переработки нефти. Основные показатели качества используемых веществ показаны в табл. 1 и 2.

Групповой углеводородный состав определяли на лабораторной установке «Градиент-М» с детектором по теплопроводности методом жидкостно-адсорбционной хроматографии с градиентным вытеснением. Данная методика позволяет с наименьшей погрешностью определить групповой состав тяжелых нефтепродуктов с разделением на семь групп: пара-

\section{Таблица 4}

Состав и групповой химический состав образцов битумов, полученных на основе сырья I и вакуумного газойля

\begin{tabular}{|c|c|c|c|c|c|c|}
\hline \multirow{2}{*}{ № образца } & \multicolumn{3}{|c|}{ Содержание компонентов, \% } & \multicolumn{3}{c|}{ Содержание, \% } \\
\cline { 2 - 7 } & Битум & Гудрон & ВГ & Масла & Смолы & Асфальтены \\
\hline 1 & 49 & 46 & 5 & 71 & 19 & 10 \\
\hline 2 & 66 & 24 & 10 & 69 & 71 & 13 \\
\hline 3 & 60 & 25 & 15 & 72 & 17 & 12 \\
\hline 4 & 60 & 20 & 20 & 69 & 19 & 12 \\
\hline 5 & 60 & 35 & 5 & 68 & 18 & 14 \\
\hline 6 & 73 & 17 & 10 & 69 & 17 & 14 \\
\hline 7 & 70 & 15 & 15 & 69 & 17 & 14 \\
\hline
\end{tabular}


RESEARCH RESULTS OF THE LEADING SCIENTISTS • РЕЗУЛЬTATЫ ИССЛЕДОВАНИЙ ВЕДУЩИХ УЧЕНЫХ

Таблица 5

Состав и групповой химический состав образцов битумов, полученных на основе сырья II и вакуумного газойля

\begin{tabular}{|c|c|c|c|c|c|c|}
\hline \multirow{2}{*}{ № образца } & \multicolumn{3}{|c|}{ Содержание компонентов, \% } & \multicolumn{3}{c|}{ Содержание, \% } \\
\cline { 2 - 7 } & Битум & Гудрон & ВГ & Масла & Смолы & Асфальтены \\
\hline 1 & 60 & 35 & 5 & 66 & 22 & 13 \\
\hline 2 & 68 & 22 & 10 & 65 & 21 & 14 \\
\hline 3 & 85 & 0 & 15 & 63 & 21 & 16 \\
\hline 4 & 65 & 30 & 5 & 65 & 22 & 13 \\
\hline 5 & 75 & 15 & 10 & 64 & 21 & 15 \\
\hline 6 & 82 & 3 & 15 & 64 & 21 & 15 \\
\hline
\end{tabular}

фино-нафтеновые углеводороды, легкие, средние, тяжелые ароматические углеводороды, смолы, асфальтены. Групповой углеводородный состав компонентов, применяемых в ходе исследований, представлен в табл. 3 .

\section{Результаты исследований}

Методом компаундирования были приготовлены образцы битумов с температурами размягчения
45 и $47^{\circ} \mathrm{C}$. Состав и групповой химический состав компаундированных битумов, полученных на основе сырья I и II и вакуумного газойля, приведены в табл. 4 и 5, а их физико-химические свойства в табл. 6 и 7.

Физико-химические свойства полученных образцов битума на основе сырья I и II представлены в табл. 6 и 7.

Анализ результатов исследований позволил установить оптимальный групповой химический состав

\section{Таблица 6}

Физико-химические свойства битумов, полученных на основе сырья I и вакуумного газойля

\begin{tabular}{|c|c|c|c|c|c|c|c|c|c|c|}
\hline \multirow[b]{2}{*}{ Показатель } & \multicolumn{8}{|c|}{ № образца битума } & \multicolumn{2}{|c|}{ ГОСТ 33133-2014 } \\
\hline & 1 & 2 & 3 & 4 & 5 & 6 & 7 & 8 & $\begin{array}{c}\text { БНД } \\
100 / 130\end{array}$ & $\begin{array}{c}\text { БНД } \\
70 / 100\end{array}$ \\
\hline $\begin{array}{l}\text { Температура } \\
\text { размягчения, }{ }^{\circ} \mathrm{C}\end{array}$ & 46 & 45 & 45 & 45 & 47 & 47 & 47 & 47 & $\begin{array}{l}\text { не ниже } \\
45\end{array}$ & $\begin{array}{c}\text { не ниже } \\
47\end{array}$ \\
\hline $\begin{array}{l}\text { Изменение температу- } \\
\text { ры размягчения после } \\
\text { старения, }{ }^{\circ} \mathrm{C}\end{array}$ & 4 & 4 & 7 & 11 & 7 & 11 & 10 & 7 & $\begin{array}{c}\text { не более } \\
7\end{array}$ & $\begin{array}{c}\text { не более } \\
7\end{array}$ \\
\hline $\begin{array}{l}\text { Изменение массы } \\
\text { образца после старе- } \\
\text { ния, \% масс. }\end{array}$ & 0 & 0 & 0 & 0 & 0,51 & 0 & 0 & 0 & $\begin{array}{c}\text { не более } \\
0,7\end{array}$ & $\begin{array}{c}\text { не более } \\
0,6\end{array}$ \\
\hline $\begin{array}{l}\text { Глубина проникания } \\
\text { иглы при } 0^{\circ} \mathrm{C} • 0,1 \text { мм }\end{array}$ & 51 & 54 & 56 & 49 & 42 & 49 & 47 & 42 & 30 & 21 \\
\hline $\begin{array}{l}\text { Глубина проникания } \\
\text { иглы при } 25^{\circ} \mathrm{C} • 0,1 \text { мм }\end{array}$ & 130 & 139 & 140 & 142 & 102 & 93 & 97 & 100 & $101-130$ & $71-100$ \\
\hline $\begin{array}{l}\text { Растяжимость } \\
\text { при } 25^{\circ} \mathrm{C}, \text { см }\end{array}$ & 77 & 48 & 73 & 65 & 45 & 37 & 18 & 62 & $\begin{array}{l}\text { не менее } \\
70 \\
\end{array}$ & $\begin{array}{l}\text { не менее } \\
\quad 62\end{array}$ \\
\hline $\begin{array}{l}\text { Температура } \\
\text { хрупкости, }{ }^{\circ} \mathrm{C}\end{array}$ & -25 & -29 & -27 & -28 & -26 & -34 & -30 & -26 & $\begin{array}{c}\text { не выше } \\
-20\end{array}$ & $\begin{array}{c}\text { не выше } \\
-18\end{array}$ \\
\hline
\end{tabular}


RESEARCH RESULTS OF THE LEADING SCIENTISTS • РЕЗУЛЬTATЫ ИССЛЕДОВАНИЙ ВЕДУЩИХ УЧЕНЫХ

Таблица 7

Физико-химические свойства битумов, полученных на основе сырья II и вакуумного газойля

\begin{tabular}{|c|c|c|c|c|c|c|c|c|}
\hline \multirow{2}{*}{ Показатель } & \multicolumn{6}{|c|}{ № образца битума } & \multicolumn{2}{|c|}{ ГОСТ 33133-2014 } \\
\hline & 1 & 2 & 3 & 4 & 5 & 6 & БНД 100/130 & БНД 70/100 \\
\hline $\begin{array}{l}\text { Температура } \\
\text { размягчения, }{ }^{\circ} \mathrm{C}\end{array}$ & 46 & 46 & 45 & 47 & 48 & 47 & не ниже 45 & не ниже 47 \\
\hline $\begin{array}{l}\text { Изменение температуры раз- } \\
\text { мягчения после старения, }{ }^{\circ} \mathrm{C}\end{array}$ & 6 & 6 & 6 & 5 & 8 & 4 & не более 7 & не более 7 \\
\hline $\begin{array}{l}\text { Изменение массы образца } \\
\text { после старения, \% масс. }\end{array}$ & 0 & 0 & 0,43 & 0 & 0,43 & 0 & не более 0,7 & не более 0,6 \\
\hline $\begin{array}{l}\text { Глубина проникания иглы } \\
\text { при } 0^{\circ} \mathrm{C} • 0,1 \text { мм }\end{array}$ & 41 & 37 & 54 & 36 & 43 & 44 & 30 & 21 \\
\hline $\begin{array}{l}\text { Глубина проникания иглы } \\
\text { при } 25^{\circ} \mathrm{C} \bullet 0,1 \text { мм }\end{array}$ & 104 & 110 & 118 & 80 & 82 & 83 & $101-130$ & $71-100$ \\
\hline Растяжимость при $25^{\circ} \mathrm{C}, \mathrm{cm}$ & 74 & 69 & 58 & 41 & 51 & 76 & не менее 70 & не менее 62 \\
\hline Температура хрупкости, ${ }^{\circ} \mathrm{C}$ & -27 & -25 & -32 & -28 & -32 & -32 & не выше -20 & не выше -18 \\
\hline
\end{tabular}

компаундированных битумов, представленный на рис. 1 и 2.

Одной их важных характеристик наноструктурированной системы битума является дисперсность, которая характеризует не только размер частиц дисперсной фазы в дисперсной системе, показывает, какое число частиц можно уложить вплотную в одном кубическом метре, но и влияет на физико-химические свойства битумного вяжущего. Чем меньше размер частиц дисперсной фазы битума, который формируется в основном асфальтенами, тем больше его дисперсность [3, 4, 19]. Дисперсность исследуемых битумов определялась по [1]. На рис. 3 показаны

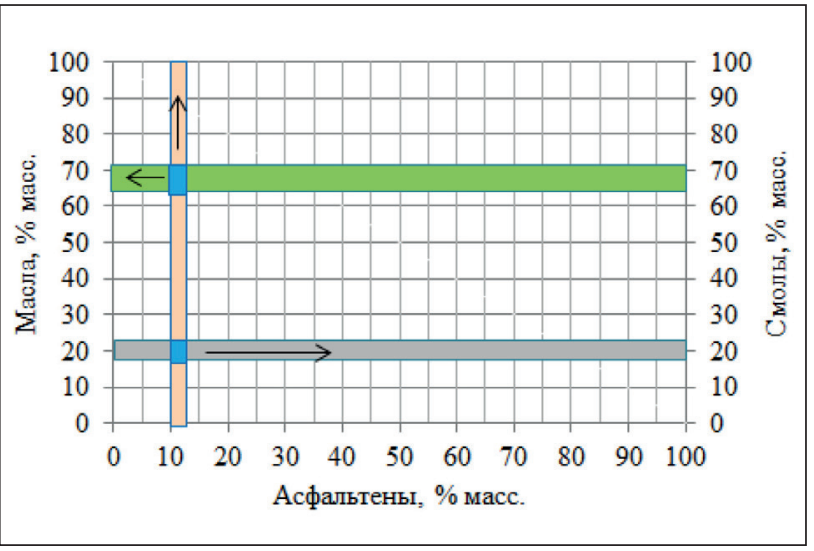

Рис. 1. Оптимальный групповой химический состав компаундированных битумов для марки БНД 100/130 зависимости отношения асфальтенов к сумме масел и смол $(\mathrm{A} /(\mathrm{M}+\mathrm{C}))$ от дисперсности компаундированных битумов.

Установлено, что чем выше дисперсность битума, тем более пластичными свойствами он обладает, кроме того снижается способность битума к термоокислительным процессам старения. Найден диапазон значений дисперсности битума $(2,7-3,5)$ и наиболее оптимальные значения отношения $\mathrm{A} /(\mathrm{C}+\mathrm{M})$ для битума марки БНД 100/130-0,11...0,15 и для битума марки БНД 70/100 - 0,16...0,18, которые обеспечат получение наноструктурированного битума типа «золь-гель».

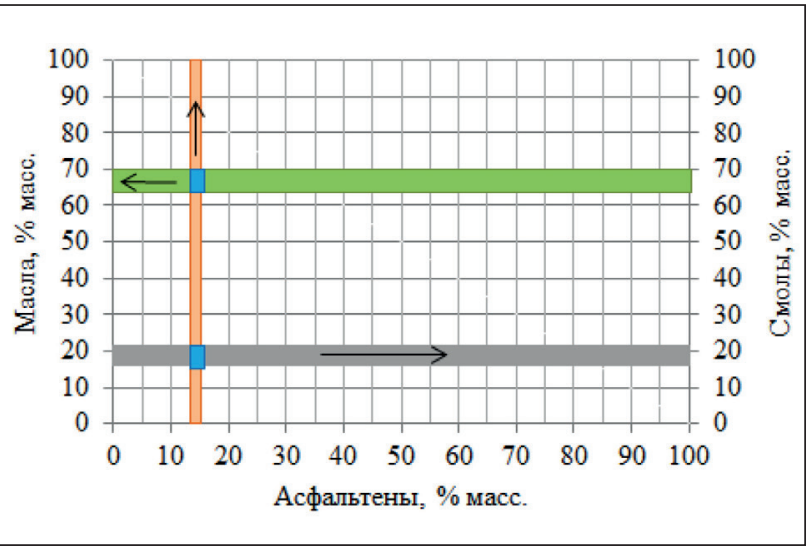

Рис. 2. Оптимальный групповой химический состав компаундированных битумов для марки БНД 70/100 


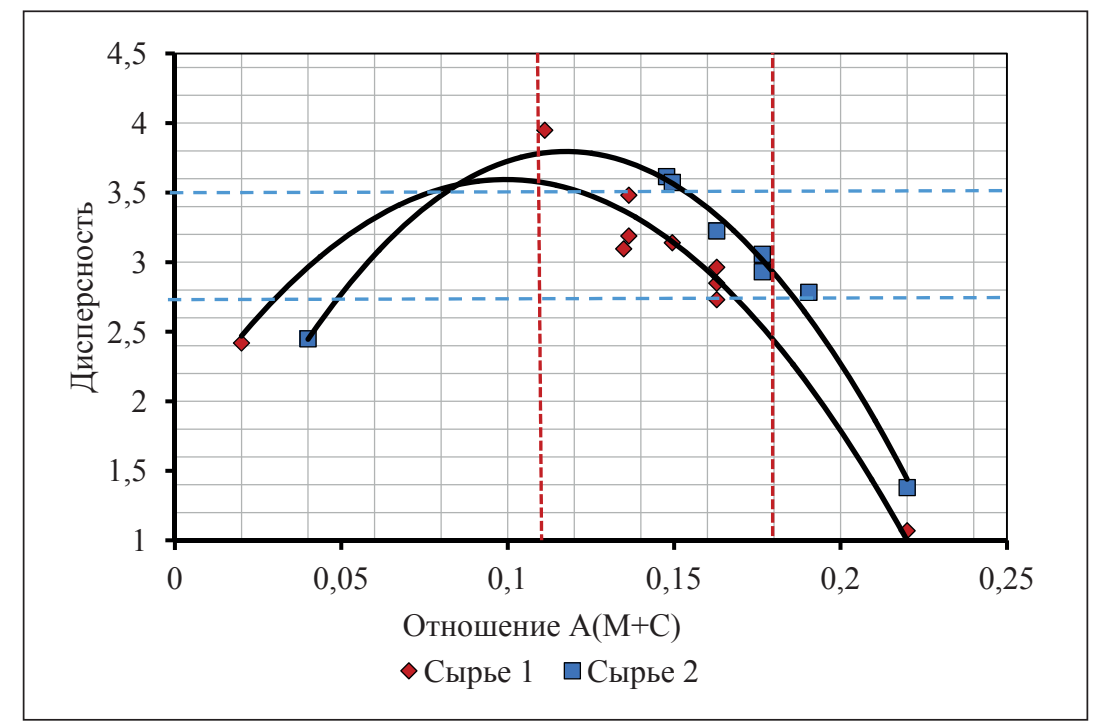

\section{Рис. 3. Зависимости отношения асфальтенов к сумме масел и смол $(\mathrm{A} /(\mathrm{M}+\mathrm{C}))$ от дисперсности компаундированных битумов, полученных на основе сырья I и II и вакуумного газойля}

\section{ЗАКЛЮЧЕНИЕ}

Таким образом, в битумном производстве методом компаундирования можно сформировать оптимальный групповой химический состав готовой продукции и с большей долей вероятности получить продукцию, соответствуюшую новому стандарту ГОСТ 33133-2014.
Современная лабораторная база нефтеперерабатывающих предприятий позволяет достаточно оперативно определять химический состав нефтепродуктов, поэтому результаты, представленные в работе, могут быть квалифицированно использованы в производстве.

\section{REFERENCES}

1. Gong R.B. Oil bitumen. Moscow: Chemistry, 1973. 432 p. (In Russian).

2. Rebinder P.A. Surface phenomena in disperse systems. Moscow: Science, 1978. 294 p. (In Russian).

3. Safieva R.Z. Physical chemistry of oil. Physical and chemical basis of oil refining technology. Moscow: Chemistry, 1998. 448 p. (In Russian).

4. Syunyaev Z.I., Safieva R.Z., Syunyaev R.I. Oil disperse systems. Moscow: Chemistry, 1990. 226 p. (In Russian).

5. Rudenskaya I.M., Rudensky, A.V. Organic binding agents for road construction. Moscow: Infra-M, 2010. 267 p. (In Russian).

6. Fryazinov V.V. Investigation of influence of hydrocarbon component on properties of bitumen: dis. cand. sc. eng.: 05.17.07. Ufa, 1975. 216 p. (In Russian).

7. Apostolov S.A. Scientific basis for the production of bitumen. Leningrad: Publishing house of LSU, 1988. 165 p. (In Russian).

8. Akhmetov B.R., Evdokimov I.N., Eliseev N.Yu. Some features of supramolecular structures in oil environment. Chemistry and technology of fuels and oils. 2002. No. 4. Pp. 41-43. (In Russian).

9. Belokon N.Yu. Kompaneets V.G., Kolpakov I.V. Investigation of the tar group composition influence on the quality of industrial oxidized bitumen. Refining and petrochemistry. 2001. No. 1. P. 19-23. (In Russian).

10. Rudenskaya I.M., Rudensky A.V. Organic binding agents for road construction. Moscow: Infra-M, 2010. 267 p. (In Russian).

11. Unger F.G., Andreeva L.N. Fundamental aspects of petroleum chemistry. Nature of resins and asphaltenes. Novosibirsk: Nauka Publ. 1995. 192 p. (In Russian).

12. Nelyubova V.V., Kobzev V.A., Sivalneva M.N., Podgornyj I.I., Palshina Yu.V. Peculiarities of nanostructured binding agents depending on the genesis of raw material. Vestnik BGTU im. V.G. Shuhova. 2015. No.2. Pp. 25-28. (In Russian).

13. Gotovtsev V.M., Shatunov A.G., Rumyantsev A.N., Sukhov V.D. Nanotechnologies in the production of asphalt concrete. Fundamental studies. 2013. No. 11. Pp. 191-195. (In Russian). 
14. Evdokimova N.G., Khartanovich K.V., Zhirnov B.S., Khannanov N.R. Receiving paving bitumen by compounding overoxidized bitumen with tar. Electronic scientific journal «Oil and gas business». 2005 No. 1. (14.01.05). http://www.ogbus.ru/authors/ Evdokimova/Evdokimova_1.pdf. (In Russian).

15. Evdokimova N.G., Sajfullina A.A., Sharipov A.V. Optimization of the paving bitumen compounding mode at the bitumen installationt of JSC "Salavatnefteorgsintez". Materials of the III all-Russian scientific and production conference on the production and use of bitumen materials. Perm: LUKOIL-Permnefteorgsintez, 2007. Pp. 29-30. (In Russian).

16. Evdokimova N.G., Alieva E.A. Production of paving bitumen according to the scheme of "oxidation-compounding" with the usage of a vacuum residue of viscosity breaking installation as a modifier of oxidation raw material. In the collection "Deep processing of oil disperse systems": materials of VI international scientific-technical conference. Moscow: TUMA GROUP, 2011. Pp. 138-140. (In Russian).

17. Kurakulov E.M., Ishkina D.P., Evdokimova N.G. Selection of components for the bitumen production according to the scheme of "oxidation-compounding" on the basis of their chemical composition. Materials of the Intern. science.-method. Conf. "Integration of science and education in oil and gas universities". Ufa: USPTU. 2018. Pp. 128-131. (In Russian).

18. Kurakulov E.M., Ishkina D.P., Evdokimova N.G. Determining the optimal chemical composition of the compounded paving bitumen. Materials of Intern. Theor. and Pract. Conf. dedicated to the 70-th anniversary of Gazprom Neftekhim Salavat. Ufa: USPTU. 2018. Pp. 36-38. (In Russian).

19. Evdokimova N.G. Development of the scientific-technological basis of modern bituminous materials production as the petroleum disperse systems. Dr. Sc. Eng. diss.]. Moscow: Russian state University of oil and gas named after I. M. Gubkin, 2015. 410 p. (In Russian).

20. Kolbanovskaya A.S. Study of disperse structures in petroleum bitumen in order to obtain optimal material for road construction: abstract of Doctorate thesis. Moscow, 1967. 43 p. (In Russian).

21. Efremov A.V. Basyrov M.I., Nikiforov N.N., Evdokimova N.G., Saifullin A.A., Kozlov Yu.M. Study of the compounding process when producing paving bitumen on bitominous installation. Refining and petrochemistry. 2008. No. 4-5, pp. 70-73. (In Russian).

22. Erich V.N. Petroleum bitumen. Chemistry and technology of oil and gas. Leningrad: Chemistry, 1985. Pp. 350-355. (In Russian).

23. Kolbanovskaya A.S., Mikhailov V.V. Paving bitumen. Moscow: Transport, 1973. 264 p. (In Russian).

24. Kolbanovskaya A.S., Davydov, A.R., Sabzi O.Y. Structure formation of paving bitumen. Physicochemical mechanics of disperse structures. Moscow: Science, 1966. Pp. 103-113. (In Russian).

\section{СПИСОК ЛИТЕРАТУРЫ}

1. Гун Р.Б. Нефтяные битумы. - М.: Химия, 1973. - 432 с.

2. Ребиндер П.А. Поверхностные явления в дисперсных системах. - М.: Наука, 1978. - 294 с.

3. Сафиева Р.3. Физикохимия нефти. Физико-химические основы технологии переработки нефти. - М.: Химия, 1998. $-448 \mathrm{c}$.

4. Сюняев 3.И., Саффиева Р.3., Сюняев Р.И. Нефтяные дисперсные системы. - М.: Химия, 1990. - 226 с.

5. Руденская И.М., Руденский А. В. Органические вяжущие для дорожного строительства. - М.: Инфра-М, 2010. - 267 с.

6. Фрязинов В.В. Исследование влияния углеводородного компонента на свойства битумов: дис. канд. техн. наук: 05.17.07. - Уфа. - 1975. - $216 \mathrm{c.}$

7. Апостолов С.А. Научные основы производства битумов. - Л.: Изд-во ЛГУ, 1988. - 165 с.

8. Ахметов Б.Р., Евдокимов И.Н., Елисеев Н.Ю. Некоторые особенности надмолекулярных структур в нефтяных средах // Химия и технология топлив и масел. - 2002. - № 4. - С. 41-43.

9. Белоконь Н.Ю., Компанеец В.Г., Колпаков И.В. Исследование влияния группового состава гудронов на качество промышленных окисленных битумов // Нефтепереработка и нефтехимия. - 2001. - № 1. - С. 19-23.

10. Руденская И.М., Руденский А.В. Органические вяжущие для дорожного строительства. - М.: Инфра-М, 2010. - 267 с.

11. Унгер Ф. Г., Андреева Л. Н. Фундаментальные аспекты химии нефти. Природа смол и асфальтенов. - Новосибирск: Наука, 1995. - С. 192.

12. Нелюбова В.В., Кобзев В.А., Сивальнева М.Н., Подгорный И.И., Пальшина Ю.В. Особенности наноструктурированного вяжущего в зависимости от генезиса сырья // Вестник БГТУ им. В.Г. Шухова. - 2015. - № 2. - С. $25-28$.

13. Готовцев В.М., Шатунов А.Г., Румянцев А.Н., Сухов В.Д. Нанотехнологии в производстве асфальтобетона // Фундаментальные исследования. - 2013. - № 11. - С. 191-195.

14. Евдокимова Н.Г., Кортянович К.В., Жирнов Б.С., Ханнанов Н.Р. Получение дорожных битумов компаундированием переокисленных битумов с гудроном // «Нефтегазовое дело». - 2005. - №1. (14.01.05). http://www.ogbus.ru/ authors/Evdokimova/Evdokimova_1.pdf.

15. Евдокимова Н.Г., Сайфуллина А.А., Шарипов А.В. Оптимизация режима компаундирования дорожных битумов на битумной установке ОАО «Салаватнефтеоргсинтез» // Материалы III Всероссийской научно-производственной конференции по проблемам производства и применения битумных материалов. - Пермь: Лукойл-Пермьнефтеоргсинтез, 2007. - С. 29-30.

16. Евдокимова Н.Г., Ялиева Э.А. Получение дорожных битумов по схеме «окисление-компаундирование» с использованием вакуумного остатка установки висбрекинга в качестве модификатора сырья окисления // В сб. «Глубокая переработка нефтяных дисперсных систем»: материалы VI международной научно-технической конференции. - М: Изд-во «Техника», ТУМА ГРУПП, 2011. - С. 138-140. 
17. Кунаккулова Э.М., Ишкина Д.П., Евдокимова Н.Г. Подбор компонентов для производства нефтяных битумов по схеме «окисление-компаундирование» на основе их химического состава // Материалы Междунар. науч.-метод. конф. «Интеграция науки и образования в вузах нефтегазового профиля». - Уфа: УГНТУ, 2018. - С. $128-131$.

18. Кунаккулова Э.М., Ишкина Д.П., Евдокимова Н.Г. Определение оптимального химического состава компаундированных дорожных битумов // Материалы Междунар. науч.-практ. конф., посвященной 70-летию ООО «Газпром нефтехим Салават». - Уфа: УГНТУ, 2018. - С. 36-38.

19. Евдокимова Н.Г. Разработка научно-технологических основ производства современных битумных материалов как нефтяных дисперсных систем: дис. док. техн. наук: 05.17.07. - М.: РГУ нефти и газа имени И.М. Губкина, $2015 .-410$ с.

20. Колбановская А.С. Исследование дисперсных структур в нефтяных битумах с целью получения оптимального материала для дорожного строительства: автореф. дис. д-ра техн. наук: 05.17.07. - М., 1967. - 43 с.

21. Ефремов А.В., Басыров М.И., Никифоров Н.Н., Евдокимова Н.Г., Сайфуллина А.А., Козлова М.Ю. Исследование процесса компаундирования при получении дорожных битумов на битумной установке // Нефтепереработка и нефтехимия. -2008 . - № 4-5. - С. 70-73.

22. Эрих В.Н. Нефтяные битумы // Химия и технология нефти и газа. - Л.: Химия, 1985. - С. 350-355.

23. Колбановская А.С., Михайлов В.В. Дорожные битумы. - М. Транспорт, 1973. - 264 с.

24. Колбановская А.С., Давыдова А.Р., Сабсай О.Ю. Структурообразование дорожных битумов. Физико-химическая механика дисперсных структур. - М.: Наука, 1966. - С.103-113.

\section{INFORMATION ABOUT THE AUTHORS}

Natalya G. Evdokimova, Doctor of Engineering, Associate Professor of Department «Chemical and Technological Processes», Ufa State Petroleum Technical University, Branch of the University in the City of Salavat; Gubkin St., 22B,

Salavat, Bashkortostan, Russian Federation, ruskih1.r@yandex.ru;

Egorova Nadezhda Aleksandrovna, Graduate Student, Senior Lecturer of Department «Chemical and Technological Processes», Ufa State Petroleum Technical University, Branch of the University in the City of Salavat; Gubkin St., 22B, Salavat, Bashkortostan, Russian Federation, kushner-nadia@mail.ru;

Sultanova Diana Petrovna, Undergraduate of Department «Chemical and Technological Processes», Ufa State Petroleum Technical University, Branch of the University in the City of Salavat; Gubkin St., 22B, Salavat, Bashkortostan, Russian Federation, d.ishkina@mail.ru;

Kunakkulova Elvira Maratovna, Undergraduate of Department «Chemical and Technological Processes», Ufa State Petroleum Technical University, Branch of the University in the City of Salavat; Gubkin St., 22B, Salavat, Bashkortostan, Russian Federation, btp1421elvira@gmail.com;

Serezhkina Natalia Gennadievna, Senior Lecturer of Department «General Scientific Disciplines», Ufa State Petroleum Technical University, Branch of the University in the City of Salavat; Gubkin St., 22B, Salavat, Bashkortostan, Russian Federation, sng-tasha@yandex.ru

\section{ИНФОРМАЦИЯ ОБ АВТОРАХ}

Евдокимова Наталья Георгиевна, д-р. техн. наук, проф. каф. «Химико-технологические процессы», ФГБОУ ВО «Уфимский государственный нефтяной технический университет», филиал УГНТУ в г. Салавате; ул. Губкина, д. 22 Б, г. Салават, Башкортостан, Россия, 453200, ruskih1.r@yandex.ru;

Егорова Надежда Александровна, аспирант, ст. преподаватель каф. «Химико-технологические процессы» филиала ФГБОУ ВО «Уфимский государственный нефтяной технический университет» В г. Салават; ул. Губкина, д. 22 Б, г. Салават, Башкортостан, Россия, 453200, kushner-nadia@mail.ru;

Султанова Диана Петровна, магистрант каф. «Химико-технологические процессы» филиала ФГБОУ ВО «Уфимский государственный нефтяной технический университет» в г. Салават; ул. Губкина, д. 22 Б, г. Салават, Башкортостан, Россия, 453200, d.ishkina@mail.ru;

Кунаккулова Эльвира Маратовна, магистрант каф. «Химико-технологические процессы» филиала ФГБОУ ВО «Уфимский государственный нефтяной технический университет» В г. Салават; ул. Губкина, д. 22 Б, г. Салават, Башкортостан, Россия, 453200, btp1421elvira@gmail.com;

Сережкина Наталья Геннадьевна, ст. преподаватель каф. «Общенаучные дисциплины» филиала ФГБОУ ВО «Уфимский государственный нефтяной технический университет» В г. Салават; ул. Губкина, д. 22 Б, г. Салават, Башкортостан, Россия, 453200, sng-tasha@yandex.ru. 